\section{SOI: $1.1 /$ TAS DOI: $10.15863 /$ TAS International Scientific Journal Theoretical \& Applied Science}

p-ISSN: 2308-4944 (print)

e-ISSN: 2409-0085 (online)

Year: 2017

Issue: 05

Volume: 49

Published: 15.05 .2017

http://T-Science.org
Fatima Avaz Bayramova junior researcher at the Institute of Economics of the National Academy of Sciences of Azerbaijan, doctoral student of the department "Psychology" of Baku State University,

Baku, Azerbaijan Republic nauka-xxi@mail.ru

SECTION 21. Pedagogy. Psychology. Innovations in the field of education.

\title{
PSYCHOLOGICAL FACTORS OF THE PERSONALITY TYPOLOGY OF THE SENIOR MANAGEMENT IN THE PROCESS OF DECISION- MAKING
}

Abstract: The article studies the theoretical and practical aspects of the impact of the leader's personality typology and leadership styles on decision-making. The article investigates quality features of the impact of the interaction of both the personality typology and the management styles of the leader to the decision-making.

Key words: Management, making decisions, leadership styles, personality types.

Language: English

Citation: Bayramova FA (2017) PSYCHOLOGICAL FACTORS OF THE PERSONALITY TYPOLOGY OF THE SENIOR MANAGEMENT IN THE PROCESS OF DECISION-MAKING. ISJ Theoretical \& Applied Science, 05 (49): 14-20.

Soi: http://s-o-i.org/1.1/TAS-05-49-3 Doi: crossef https://dx.doi.org/10.15863/TAS.2017.05.49.3

\section{Introduction}

Each person has a specific attitude towards his work and his colleagues. This attitude is formed on the basis of education, life experience, and social environment. The relationships in the team are revealed by the overall psychological atmosphere. The acceptable psychological environment, business process, and its results are compared with the level of consent by the relationships with other people. Analysis of the leader's personal qualities, characteristics, personality type and other attributes in the process of decision-making allow the researcher to get interesting results. It allows defining how the confident is the leader in his knowledge, attitude towards the surrounding environment, factors on which he bases his decisions, and rational and irrational features of the taken decisions. Many researchers have conducted extensive studies and investigations in this area. The most famous classification of the types of personality has been provided by the Swiss psychologist, K. Young. Extravert and introvert types of personalities, suggested by K. Young, have become widespread. Extraverts are characterized as being pathetic, initiative, tough, inherent in interpersonal skills. Introverts are characterized as being reserved, thoughtful, non-social, self-analyzing, finding it difficult to adapt [3.p.244]. We can also add MyersBriggs to the list of psychologists who provided their input into the classification of the personality types.
In her works, she relies on the four psychological functions described in K. Young's "Psychological Types" [10.p.335] book written in 1921: thinking, feeling, intuition and sense. Myers - Briggs' typology (MBTI) [5.p.223-228] enables the measurement of the characteristic features and qualities of a combination of personal factors, the inclination of the person towards any kind of activity, the decision-making process and other qualities. In order to study these qualities more thoroughly, there were formed 4 scales (tags) representing the personality:

1. Orientation of consciousness ([E] extraversion - [I] Introversion);

2. Orientation of circumstances ([S] Sensing common sense - $[\mathrm{N}]$ Intuition);

3. The basis for the adoption of a decision ([T] Thinking - $[\mathrm{F}]$ Feeling);

4. Decision-making skills ([J] Judging rationality - $[\mathrm{P}]$ Perception - irrationality). [5, p. 224].

In Azerbaijani literature, there is an interesting typology classification developed by the psychologist S. Majidova (the character typology called "69"). [7. p.155] This typology is based on the individual's stages of self- consciousness. The author distinguishes three stages of self-consciousness in the evolution of human development. The first stage of self-consciousness is characterized by the following features: egocentrism, different perception of the 
world in the criteria of "my-mine-not mine"; consumeristic attitude towards everything, focusing on the material side. The second stage of selfconsciousness is characterized by feeling united and being a part of the community instead of egocentrism. The old environment of "my-not mine" is expanded with a new shade of differentiation. The "I" is replaced by "we".

The main characteristic of the third level of self-consciousness is the lack of differentiation, and the infinity of space and time, understanding the relationship with the outside world, accepting the unity of the world, following spiritual principles of the universe [3, p.213].

The leader's time management practices depending on the personality type

Time management practices differ depending on the personality type.[1.p.23] Leaders of the introvert type have the ability to use time effectively. Before taking any issue for discussion they tend to conduct a comprehensive review of information. Extraverts, on the contrary, put any idea to discussion straight away, arrange dialogues and take the decision afterward. This means the waste of time. Extravert leaders waste not only their time but also of those involved in the discussion, the introverts, and other extraverts. The extraverts should understand that sooner or later they will need to stop the communication and make the decision. During the discussion, the extravert leader should give their introvert employees a 5-minute break for them to think over the issue and come up with any thoughts and views. The introverts, in their turn, should understand that they should not overthink the process, take the decision more quickly, get involved in dialogues and allow the extraverts to express their opinion.

The reason of the most problems is in handling time differently by different people. People of sensing type perceive 60 seconds as 1 minute, while people of intuitive type think that 1 minutes is too little. For this type of people, it is necessary to add one hour on top of the time allotted to the task. Intuitive type employees in their turn should know that if a sensitive type leader gives them the task they need to perform with the given timeframe. People of sensing type manage their time during implementation of any task depending on their attitude towards any specific person. This type of people tends to drag the time of implementation of the task to the very end. However, people of the logical type tend, on the contrary, to complete the tasks related to unpleasant people in the first place in order to get rid of them as soon as possible.

People of the rational type like to manage the time of their own and that of the other people. Due to being very punctual, these people tend to put time limitations to all tasks, even those that are implemented by them themselves.

People of perceiving type tend to constantly procrastinate. They are extending the decisionmaking process, wasting their time on the meaningless things. In many cases, the people of irrational type want to take several decisions at once, starting one project without completing the previous one. As a result, all the work remains unfinished. The utmost thing that the people of the irrational type should do in order to complete their work is to put deadlines for all their projects. On the contrary, the people of the rational type, tend to get irritated when they are faced with completing the projects that have not been planned in advance.

\section{The impact of the leader's personality type on the management decisions}

In many cases, the extravert leaders would tell something without giving it a prior thorough thought. They are usually led by the commonly accepted processes, used for the benefit of everyone, and fitting the targeted result.

Rational extraverts identify the goals and objectives first, communicate these to the employees and urge everyone to start operations immediately.

Perceiving extraverts, first of all, start to discuss the issue with their team, regardless of its complexity.

The introvert leaders, first of all, gather all available information about the issue, think it over alone, and only after that take it to discussion with their team. People of introvert type do not share the information in the truthfulness of which they are not confident. Collective decision-making is not important for introvert individuals, as this process represents an internal value for them.

Thus, for the decision-making process to be effective, it is important to create an environment where extravert leaders could discuss the problem with their team, and introvert leaders could give it a thought prior to taking a decision.

Unlike the extravert leaders, introvert leaders prefer to start operations immediately rather than generating various ideas. In the joint effort, both the extraverts and the introverts should follow a set of certain rules. Extravert leaders should address their introvert employees with precise questions. For example, instead of asking "What do you think about this issue?" they should ask "What is your opinion about the first point?".

According to Karl Gustav Young, the extraversion and introversion show the deepest gap in the relationships among the people. The founder of this theory, Carl Gustav Jung believed that extraversion and introversion are innate properties that have a physiological basis. Modern science has confirmed the correctness of his intuitive guesses. He argued that we can best adapt in this world, moving 
along the continuum from the introvert to the extrovert edge of the spectrum, when we need it. In Jung's opinion, in addition to extremes, one can be at any point of the continuum, and this is quite normal. However, we are always drawn in one direction more strongly than in the other. Everyone has a "comfortable niche" where we function in the best possible way. [9, p. 23]

Otto Kroeger and Janet Tewsen [4, p.33] psychologist consultants who use the Myers-Briggs personality type indicator in their work, discuss the unenviable position of the introvert in their book "About Type of Personality": Introverts are less more than three times. As a result, they must develop additional skills that will help them cope with the tremendous pressure from society that requires them to "comply" with all its other members.Indeed, the difference between the behaviour of extravert and introvert is deep and contradictory, and this significantly determines the style of leadership. Extravert leaders give preference to the verbal communication and do not hesitate to speak openly event about the very sensitive topics. The weakness of extravert leaders is that they share their plans regardless of whether there is a need to do so or not. Extravert leaders prefer to talk rather than listen.

The research and developed theories were conducted studying mostly extravert type of people. According to the theories that were put forward as a result of those studies, it was recommended to all leaders to communicate with each member of their team and get familiar with their work and life challenges. However, this type of recommendations did not take into the account the introvert type of leaders, which caused the introverts to leave their comfort zone on a constant basis. Or, the "open door policy" which became very popular at one period of time. According to this method, the employees were able to access the office of their management at any time. However, this type of working environment would suite only extravert type of leaders.

Unlike extraverts, the introvert leaders share the final idea with their employees without providing their inner thoughts which led to this decision. The weakness of introvert leaders is in taking a lot of time to take a decision.

Personality types impacting the management efficiency and experimental analysis of the management styles

Alongside with his interest, the leader should take into account the employees' interest as well when taking any decision. The desired result can be achieved on the basis of mutually beneficial relations and the creation of a healthy climate in the team. However, the leader's personal psychological type provides important impact in the decision-making process. Management styles analysis provided by K. Levi, [8.p.130] allows us to understand the main goal of the management. The essence of management styles that affects the decision-making can be interpreted in the following way:

Authoritarian style. The leaders preferring the authoritarian style keep the distance between themselves and their staff and avoid non-formal relationships. Authoritarian leaders control every little process and piece of work. He is concerned not only with the result of the work but also with the process. All decisions are taken by him. Authoritarian leader shares only that information which is related to work. As a rule, authoritarian governing style is strict, demanding, focused and power-concentrating.

Democratic style. The democratic leader establishes friendly relations with his employees. He draws the line between himself and his employees in terms of work responsibilities and takes into consideration the opinion of the team during the decision-making. This type of leader is interested in the result, not in the process of the work. Alongside with the team's work, he gathers all the information related to the task.

Liberal style. The liberal leader establishes informal relations with his team and delegates the majority of work responsibilities. Employees are given the highest authority, everyone carries out its work in an independent way and decisions are taken in a collective manner. The management interferes with the process only when necessary, controls the process and stimulates activity. [2.p.213]

One of the most modern of the model of leadership styles proposed by American scientists V.Vruman and F.Yetton. They, depending on the situation, the characteristics of the team and the characteristics of the problem, divided the leaders into 5 groups according to the styles of leadership:

1. The manager makes decisions himself on the basis of available information.

2. The supervisor informs the subordinates the essence of the problem, listens to their opinions and makes decisions.

3. The head issues the problem to the subordinates, summarizes the opinions expressed by them and according to the opinions makes his own decision.

4. The leader discusses the problem with his subordinates, and as a result develops a common opinion.

5. The head constantly works together with a group that either develops a collective decision, or accepts the best, regardless of who is the author. [11, p.323]

It should be noted that "pure" styles are not common. As a rule, the management style is a mixture of at least two of the styles. However, one of them is always dominant.

In addition to leadership styles, it is useful to determine the type of personality of the leader in 
order to understand which type is the most efficient in the business activity. According to Myers Briggs' typology, [6.p.23-25] it is possible to identify the leader's inclination of his consciousness, his attitude to the surrounding environment, the basis of decision-making, using the rational or irrational approach. According to her typology classification, there are the following personality types:

ESTJ - (extraversion, sensing, thinking, judging) leaders of this type are realists in their nature and have administrative, organizational and management capabilities. Hard-working and highly adaptive to any social environment, people of this personality type tend to complete their work when starting working on any task. Before starting the activity, they plan it thoroughly, giving preference to a more pragmatic and realistic approach. ESTJ personality type is held by $11 \%$ of men and $6 \%$ of women.

ENTJ - (extraversion, intuition, thinking, judging) people of this type have leadership and entrepreneurial skills, are able to clearly recognize their skills and capabilities, start to work with enthusiasm, love to be involved in various sports. These people feel new trends, rely on their intuition and take risks. They use new technologies in their business activities and are fond of conducting an indepth analysis of themselves and the world around them. They like to closely communicate with people, provide leadership, and have positive thinking. ENTJ type of personality is found in $3 \%$ of men and $1 \%$ of women.

ISTJ - (introversion, sensing, thinking, judging) people of this type have organizational and analytical capabilities. They like order and accuracy in their work and analyze all received information before starting to work. They are realistic towards their surrounding environment and start the work only if they feel that they can complete it. They can inject self-confidence in people around them, however, they tend to avoid close contacts. They immediately research any received information. This type of personality is found in $16 \%$ of men and $7 \%$ of women.

ENFJ - (extraversion, intuition, feeling, judging). ENFJ type of people are exorbitantly emotional and are inclined to empathize, have expressive mimics, and oratory ability. They can foresee the future, and have the ability to expose the lies of others, be it a verbal or emotional lie. This personality type is found in $3 \%$ of women and $2 \%$ of men.

ESFJ - (extraversion, sensing, feeling, judging). These people love teaching and educating others, they are very enthusiastic and can manage people using emotional control and are able to maintain good relationships. They are ready to sacrifice their own interests in the favour of others. They like to achieve everything on their own, and love to boast about their skills and capabilities sin front of other people. This type of personality is found in $17 \%$ of women and $8 \%$ for men.

INTJ (introversion, intuition, thinking, judging) type of people have the ability to separate the inessential from the essential, do not like the meaningless socialization, and prefers practical thinking. This type of people demonstrate independence in their activities and like to generate non - conventional ideas. When they do not have the precise answer, they tend to take intuitive decisions. They do not like noisy parties, and experience difficulties in establishing relationships with other people. Their rich inner world enables them to develop unlimited skills. Words, plans, projects, ideas, and people - they are ready to implement everything better than it exists in reality. In their view, even the most beautiful results can be even more beautiful. This type of personality is found in $3 \%$ of men and $1 \%$ of women.

INFJ - (introversion, intuition, feeling, judging). Inspiring, coaching, humanist type of people, they feel the relationships between people very precisely, trust is very important for them, and they do not forgive betrayal. They can reveal hidden skills of others, and have the ability to educate. They prefer self-education, and people often turn to them for advice. INFJ is found in $2 \%$ of women and $1 \%$ of men.

$I S F J$ - (introversion, sensing, feeling, judging). This type of people have executive, preventive, protective characteristics, they control psychological distance, separating people around them into two groups - their people and alien people, they immediately feel if someone is not sincere. They are able to defend themselves and people around them and are good at analysis. In addition to being accurate and compassionate, they are executive and caring and consider it to be their duty to help others around them. This type of personality is observed in $19 \%$ of women and $8 \%$ of men.

ENTP - (extraversion, intuition, thinking, perceiving). People of this type are researchers and dreamers in their nature, they have the wide range of interests, and are capable of learning new terms quickly and adapting to new working methods easily. These people like new ideas and are far from the traditional type of mentality. Their urge to discover something new is showing itself in professional and non-professional spheres. ENTP type of personality gives continuous preference to new ideas. This type is found in $4 \%$ of men and $2 \%$ of women.

ESTP - (extraversion, sensing, thinking, perceiving). They are determined to win at all costs. Obstacles only increase their determination. They prefer to lead, rather than to obey. Having analyzed the situation, they are able to build a clear plan and follow it carefully. Their attention focuses on the people and external environment. In their next steps, 
they objectively analyze the information and evaluate it. People of this type are able to produce objective, practical, valuable, accurate, fast and clear response in any situation. This personality type is found in $6 \%$ of men and $3 \%$ of women.

ENFP - (extraversion, intuition, feeling, perceiving). These people have the ability to understand others and possess very good imagination. They prefer creative activities over the monotonous work. People of ENFP type are very social and like to share practical advice to other people. This type of personality is observed in $10 \%$ of women and $6 \%$ of men.

ESFP - (extraversion, sensing, feeling, perceiving. Animators, politicians, activists, this type of people manipulate other people being able to understand their capabilities and skills. Being able to identify weaknesses, they take weak employees under their control. They love to look unique, however, they do not have this attribute. The act based on "here and now" principle. These people are guided only by the present, and they give preference to starting the work, rather than to completing it. Communication is important for this type of people, and they try to spend every minute in useful interaction with others. This type is observed in $10 \%$ of women and $7 \%$ of men.

INTP - (introversion, intuition, thinking, perceiving). Architect, critic, analytic, the INTP type of person is a philosopher. In addition to being attentive, these people tend to analyze the connection between the past and the future and take the decision only when they are confident that the decision correct and accurate. The are willing to explore and analyze everything. Their propensity for objectivity makes them analyze all information carefully and their mobility and dynamism allows them to perceive new information. This type is found in $5 \%$ of men and $2 \%$ of women.

ISTP - (introversion, sensing, feeling, perceiving). Masters and professionals, senses are very important for this type of people. These people like other people, reject the artificialness and are very sincere in everything they do. People of ISTP type of personality have technical thinking and love creating something with their hands. They take decisions by

analyzing the information and take the objective decision afterward. This type of personality is found in $9 \%$ of men and $2 \%$ of women.

INFP - (introversion, intuition, feeling, perceiving). These people like to dream and have lyrical personality, they are able to forecast events in an intuitive way, interact with other people in a fruitful way and feel them. They consider appearance to be important and prefer rest over working, they have difficulties with saving money. This type is observed in $5 \%$ of women and $4 \%$ of men.

ISFP - (introversion, sensing, feeling, perceiving). These people love to enjoy every moment of life, like traditionalism and monotony, respect other people's personal and private lives, and expect the same behaviour from others. They like to joke and avoid conflict situations. They love to be seen as valuable and needed and are quick to help. Gentle and caring, practical and dreaming, these type of people do not like to manage and influence others, they accept this world as it is. This type of personality is found in $10 \%$ of women and $8 \%$ of men.

We have conducted an experiment to identify the leadership style and personality types based on Kurt Lewin's and Myers-Briggs' studies.

The object of the study: 23 Heads of Departments (8 women and 15 men) of the Economic Institute of the Azerbaijan National Academy of Sciences and 12 Heads of Departments (6 women and 6 men) of the Medical Compulsory Insurance Agency.

The subject of the study: To study psychological characteristics of the impact of leadership styles on the management effectiveness.

The main hypothesis of the study: the effectiveness of the management is in functional dependence on the correlation between the leadership style and the type of personality.

The purpose of the study: to determine the relationship between leadership styles and the personality type of the leader.

The research method: Myers-Briggs' "Personality Types" and "Leadership Style SelfAssessment" surveys.

Results.

Table 1

Correlation of the leadership styles and personality types of high-level management of the department according to the annual report

\begin{tabular}{|c|c|c|c|c|c|c|}
\hline \multirow[t]{2}{*}{ Leadership styles } & \multicolumn{6}{|c|}{ Personality types } \\
\hline & ESTJ & ESFJ & ENTJ & ISTJ & INTJ & INFP \\
\hline $\begin{array}{l}\text { Authoritarian }(3 \\
\text { people }-8,5 \%)\end{array}$ & $\begin{array}{c}1 \text { person - } \\
2,8 \%\end{array}$ & 0 & $\begin{array}{c}2 \text { people - } \\
5,7 \%\end{array}$ & 0 & 0 & 0 \\
\hline $\begin{array}{l}\text { Democratic } \\
(14 \text { people - } \\
40 \%)\end{array}$ & $\begin{array}{c}5 \text { people - } \\
14,2 \%\end{array}$ & $\begin{array}{c}1 \text { person - } \\
2,8 \%\end{array}$ & $\begin{array}{c}1 \text { person - } \\
2,8 \%\end{array}$ & $\begin{array}{c}4 \text { people - } \\
11,4 \%\end{array}$ & $\begin{array}{c}2 \text { people - } \\
5,7 \%\end{array}$ & $\begin{array}{c}1 \text { person - } \\
2,8 \%\end{array}$ \\
\hline Liberal -0 & 0 & 0 & 0 & 0 & 0 & 0 \\
\hline Total & $17,1 \%$ & $2,8 \%$ & $8,5 \%$ & $11,4 \%$ & $5,7 \%$ & $2,8 \%$ \\
\hline
\end{tabular}




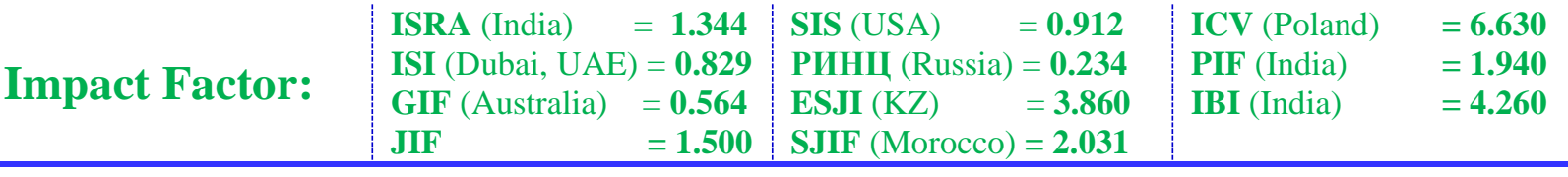

Table 1 - As a result of a conducted survey conducted, there were identified the leadership styles and personality types of high-level management of the department. As seen from the table, the democratic style of leadership prevails over others $(40 \%)$. There are $8 \%$ authoritarian leaders, and $0 \%$ liberal leaders. The percentage of personality types in democratic style of leadership is as follows: ESTJ $14.2 \%$, ESFJ, 2.8\%, 5.7\% ENTJ, ISTJ - 11.4\%, INTJ $-5.7 \%$, INFP $-2.8 \%$. Authoritarian leaders: $2.8 \%$ ESTJ, $5.7 \%$ - ENTJ.

Table 2

Correlation of the leadership styles and personality types of mid-level management of the department according to the annual report

\begin{tabular}{|c|c|c|c|c|c|c|c|c|}
\hline \multirow[t]{2}{*}{ Leadership styles } & \multicolumn{8}{|c|}{ Personality types } \\
\hline & ESTJ & ESFJ & ENTJ & ENFP & ISTJ & ENFJ & INTJ & INFP \\
\hline $\begin{array}{l}\text { Authoritarian } \\
4 \text { people - } \\
(11,4 \%)\end{array}$ & $\begin{array}{c}2 \text { people } \\
-5,7 \%\end{array}$ & 0 & 0 & $\begin{array}{c}1 \text { person - } \\
2,8 \%\end{array}$ & 0 & 0 & $\begin{array}{c}1 \text { person } \\
-2,8 \%\end{array}$ & 0 \\
\hline $\begin{array}{l}\text { Democratic } \\
(5 \text { people }-14,2 \%)\end{array}$ & $\begin{array}{c}2 \text { people } \\
-5,7 \%\end{array}$ & $\begin{array}{c}2 \text { people } \\
- \\
5,7 \%\end{array}$ & 0 & 0 & $\begin{array}{c}1 \\
\text { person } \\
-2,8 \%\end{array}$ & 0 & 0 & 0 \\
\hline $\begin{array}{l}\text { Liberal (4 people } \\
-11,4 \% \text { ) }\end{array}$ & 0 & $\begin{array}{c}1 \text { person } \\
- \\
2,8 \%\end{array}$ & $\begin{array}{c}1 \text { person } \\
-2,8 \%\end{array}$ & 0 & 0 & $\begin{array}{c}1 \text { person } \\
-2,8 \%\end{array}$ & 0 & $\begin{array}{c}1 \text { person - } \\
2,8 \%\end{array}$ \\
\hline Total & $11,4 \%$ & $8,5 \%$ & $2,8 \%$ & $2,8 \%$ & $2,8 \%$ & $2,8 \%$ & $2,8 \%$ & $2,8 \%$ \\
\hline
\end{tabular}

The Table 2 shows that there are 11,4 \$ authoritarian leaders, $14,2 \%$ democratic leaders and $11,4 \%$ liberal mid-level management in the department. Authoritarian leaders have the following types of personality: 5,7\% ESTJ, 2,8\% ENFP, 2,8\%

INTJ; democratic - 5,7\% ESTJ, 5,7\% ESFJ, 2,8\% ISTJ; liberal - 2,8\% ESFJ, 2,8\% ENTJ, 2,8\% ENFJ, $2,8 \%$ INFP.

Table 3

Correlation of the leadership styles and personality types of junior-level management of the department according to the annual report

\begin{tabular}{|c|c|c|c|c|c|c|c|c|c|}
\hline \multirow{2}{*}{$\begin{array}{l}\text { Leadership } \\
\text { style }\end{array}$} & \multicolumn{9}{|c|}{ Personality types } \\
\hline & ESTJ & ESFJ & ENTJ & ENFP & ISTJ & ISTP & ISFP & INTJ & INFP \\
\hline $\begin{array}{l}\text { Authoritarian } \\
(1 \text { person - } \\
2,8 \%)\end{array}$ & 0 & 0 & 0 & $\begin{array}{c}1 \text { person } \\
-2,8 \%\end{array}$ & 0 & 0 & 0 & 0 & 0 \\
\hline $\begin{array}{l}\text { Democratic } \\
(2 \text { people - } \\
5,7 \%)\end{array}$ & $\begin{array}{c}1 \text { person } \\
-2,8 \%\end{array}$ & 0 & 0 & 0 & 0 & 0 & 0 & 0 & $\begin{array}{c}1 \text { person } \\
-2,8 \%\end{array}$ \\
\hline $\begin{array}{l}\text { Liberal }(2 \\
\text { people }-5,7 \%)\end{array}$ & 0 & 0 & 0 & 0 & 0 & $\begin{array}{c}1 \\
\text { person } \\
-2,8 \% \\
\end{array}$ & $\begin{array}{c}1 \\
\text { person } \\
-2,8 \% \\
\end{array}$ & 0 & 0 \\
\hline Total & $2,8 \%$ & 0 & 0 & $2,8 \%$ & 0 & $2,8 \%$ & $2,8 \%$ & 0 & 0 \\
\hline
\end{tabular}

The Table 3 shows that $2,8 \%$ of the junior-level management of the department have authoritarian leadership style, $5,7 \%$ - democratic, and 5,7\% liberal leadership style. Among authoritarian leaders 2,8\% have the ENFP type of personality; democratic - 2,8 $\%$ ESTJ, 2,8\% INFP; liberal 2,8\% ISTP, 2,8\% ISFP.

According to the received results, $40 \%$ of those leaders who highly valued their department had democratic style, $14,2 \%$ of those had ESTJ type of personality (extraversion, sensing, thinking, judging) and $11,4 \%$ had ISTJ type of personality (introversion, sensing, thinking, judging).

\section{Conclusion}

The study conducted in practical and theoretical direction concluded that effective management depends on the personality type and leadership style. The leader's personality type affects both his own job performance and that of his employees. Our practical research has clearly shown that the most are clear effective leadership style is the democratic style. At the same time, it also became clear that none of the departments which had leaders of the liberal leadership style have been rated with good results. Liberal and authoritarian leadership styles were present in the departments having the average 


\begin{tabular}{l|lrl|l|ll} 
& ISRA (India) & $=\mathbf{1 . 3 4 4}$ & SIS (USA) & $=\mathbf{0 . 9 1 2}$ & ICV (Poland) & $=\mathbf{6 . 6 3 0}$ \\
Impact Factor: & ISI (Dubai, UAE) $=\mathbf{0 . 8 2 9}$ & PUHL (Russia) $=\mathbf{0 . 2 3 4}$ & PIF (India) & $=\mathbf{1 . 9 4 0}$ \\
& GIF (Australia) & $\mathbf{0 . 5 6 4}$ & ESJI (KZ) & $=3.860$ & IBI (India) & $=\mathbf{4 . 2 6 0}$ \\
& JIF & $\mathbf{1 . 5 0 0}$ & SJIF (Morocco) & $=\mathbf{2 . 0 3 1}$ & & \\
\hline
\end{tabular}

performance. According to Myers-Briggs classification, the departments distinctive for the best performance had the leaders of ESTJ (Extraversion, sensing, thinking, judging) and ISTJ (introversion, sensing, thinking, judging) personality types.

As a result, the departments having the best performance had leaders who were extraverts, introverts, sensing, thinking and judging types of personality. Both Democrats having ESTJ and ISTJ types of personality are the most effective and successful leaders.

\section{References:}

1. Sh. T. Guliyeva "Management Psychology", "Fairytale House" Publishing House, Baku 2008. p. 21-25

2. "Materials of 19th Republican Scientific Conference of Doctoral Students and Young Researchers", II book, Baku - 2015. p.213-214.

3. R. Aliyev "Psychology", "Nurlan", Baku 2008, p. 244.246

4. Otto Kroeger, Janet M. Thuesen «Type Talk: The 16 Personality Types That Determine How We Live, Love and Work» 2005 - AST, Astrel, p.33

5. Myers-Briggs Isabel, Myers Peter B. «MBTI: Definition of Types. Everybody Has A Talent», Pretext, 2012, p.223-228
6. Isabel Briggs Myers, Linda K. Kirby, Katharine D. Myers, "Introduction to Type: A Guide to Understanding Your Results on the MyersBriggs Type Indicator", Oxford Psychologists Press, 2000, p. 23-25

7. Svetlana M. Psychological types. Typology 69, Baku, "Zia, Nurlan" publishing house, 2001, p.155.

8. Paul Kleinman .PSYCH101. «Psychology facts, basics, statistics, tests, and more»,F $+\mathrm{W}$ Media Inc., 2012, p.130

9. Marty Laney. Advantages of introverts. - M: Mann, Ivanov and Ferber, 2013.p.23

10. C. G. Jung "Psychological Types".1921.p.335

11. Victor H. Vroom, Philip W. Yetton "Leadership and Decision-Making"1973, p. 323 